\title{
Modern Contraception Among Adolescent Girls and Young Women at Pikine Health Center (Dakar, Senegal)
}

Omar Gassama*, Aminata Niass, Babacar Biaye, Mor Cissé, Khalifa Mansour Fall, Fatou Mbaye Ndiaye, Marieme Gueye Ba, Alassane Diouf and Jean Charles Moreau

Obstetrics and Gynecologic Clinic, Aristide Le dantec University Hospital, Senegal

Submission: November 14, 2019; Published: November 21, 2019

*Corresponding author: Omar Gassama, Obstetrics and Gynecologic Clinic, Aristide Le dantec University Hospital, Senegal

\section{Introduction}

In Senegal, according to the 2013 report of the National Agency of Statistics and Demography (NASD), maternal mortality is estimated at 434 per 100,000 live births. With a fertility rate of 5 children per woman, family planning, a major strategy to reduce maternal and infant mortality, has increased significantly. Indeed, according to the 2014 Continuous Demographic and Health Survey, contraceptive prevalence moved from $12 \%$ in $2010-2011$ to $20.3 \%$ in 2014 [1]. However, unmet need for contraception has increased by $29 \%$. The 2011 Multiple Indicator Cluster Demographic and Health Survey (MIC-DHS) revealed that adolescent girls constituted 22 per cent of all women of childbearing age. They also represent nearly $10 \%$ of all female fertility in Senegal. This survey also revealed that for women, $56 \%$ had had sexual intercourse before the age of 20 [2]. Sexual activity among adolescents and youngsters is often correlated with risky behaviors that expose them to unwanted pregnancies and their complications. Thus, for adolescents and young people who are already sexually active, the prevention of high-risk pregnancies through family planning is a public health concern to avoid the dramatic consequences associated with unwanted pregnancies. The objective of our survey is to study contraceptive practices among adolescents girls and young women at Pikine Health Center.

\section{Clients and Methods}

This was a retrospective, descriptive and analytical study over a 12-month period (January 1 to December 31, 2013) on contraceptive use among adolescents girls and under 25 young women at the maternity ward at Baye Talla Diop Health Center in Pikine. We included all clients under 25 who had received a contraceptive method. We excluded all those who were 25 or more. Data collection was done through the family planning record, which identified socio-demographic characteristics, medical and surgical history, eating habits, clinical examination results, con traceptive method and side effects. We processed data and analysis with Epi info 3.5 software.

\section{Result}

Table 1: Distribution of patients by socio-demographic characteristics.

\begin{tabular}{|c|c|c|}
\hline Socio-Demographic Features & Number (N) & Percentage (\%) \\
\hline \multicolumn{3}{|l|}{ Age } \\
\hline Less than 20 Years & 46 & 20 \\
\hline More than 20 Years & 185 & 80 \\
\hline \multicolumn{3}{|l|}{ Marital Status } \\
\hline Married & 203 & 88 \\
\hline Single & 28 & 12 \\
\hline \multicolumn{3}{|l|}{ School Level } \\
\hline Uneducated & 91 & 39.4 \\
\hline Educated & 140 & 60.6 \\
\hline Primary school level & 78 & 55.8 \\
\hline Secondary school level & 58 & 41.4 \\
\hline Higher study level & 4 & 2.8 \\
\hline \multicolumn{3}{|l|}{ Profession } \\
\hline Housewife & 174 & 75.3 \\
\hline Employee & 57 & 24.7 \\
\hline \multicolumn{3}{|l|}{ Parity } \\
\hline Nulliparous clients & 3 & 6.9 \\
\hline Primiparous clients & 105 & 45.5 \\
\hline Pauciparous clients & 71 & 30.7 \\
\hline Multiparous clients & 52 & 16.9 \\
\hline
\end{tabular}

231 clients out of a total number of 713 new clients - young women and adolescent girls representing a frequency of $32.25 \%$ - have received contraceptive methods at the Pikine Health Centre. The clients were between 15 and 24 years of age. Among them, $20 \%$ were teenage girls $(n=46)$ and $80 \%$ were young 
women $(\mathrm{n}=185)$. The average age was 21.2 years. The average parity was 2 with extremes of 0 and 5 . Clients were mainly primiparous $(n=105)$ or $45.5 \%$ of clients, followed by pauciparous clients $(n=71)$ or $30.7 \%$ of clients. Multiparous, nulliparous and large multiparous clients accounted for $10.8 \%, 6.9 \%$ and $6.1 \%$ of clients respectively (Table 1$)$. The majority of clients were married $(n=203)$ or $88 \%$. A number of 26 single clients were identified $(11 \%)$ and 91 clients (39.4\%) were uneducated.

Table 2: Distribution of patients by socio-demographic characteristics.

\begin{tabular}{|c|c|c|c|c|c|c|}
\hline \multicolumn{7}{|c|}{ Continuity Rate (P Value= 0.000) } \\
\hline & Injectables & Oestrogen-Progesterone Pills & Jadelle & Progesterone Pills & Intra-Uterine Device & Total \\
\hline Active & $68(59.1)$ & $10(8.7)$ & $26(22.6)$ & $8(7.0)$ & $3(2.6)$ & 115 \\
\hline Stoppages & $4(66.7)$ & $2(33.3)$ & $0(0.0)$ & $0(0.0)$ & $0(0.0)$ & 6 \\
\hline Dropouts & $7(63.6)$ & $0(0.0)$ & $0(0.0)$ & $4(36.4)$ & $0(0.0)$ & 11 \\
\hline Lost to follow-up & $69(69.7)$ & $19(19.2)$ & $3(3.0)$ & $5(5.1)$ & $3(3.0)$ & 99 \\
\hline
\end{tabular}

Among the 231 adolescent girls and young women enlisted in 2013 at Pikine Health Centre, 115 were still active clients or $49.8 \%$ at the time we were collecting data. A lost to follow-up rate of $42.9 \%$ was also noted. Abandonments accounted for $4.8 \%$ and stoppages accounted for $2.6 \%$ of clients. The continuity rate was strongly linked with the type of contraception as reported in Table 2.

The choice of contraceptive method was linked to educational level and exclusive breastfeeding. Injectable contraceptive use rates were estimated at $64.8 \%$ for uneducated clients, $70.1 \%$ for

clients with primary school level, and $58.6 \%$ for clients with secondary school level. For estrogen-progestogen pills, rates ranged from $15.4 \%$ for uneducated clients, to $5.2 \%$ for clients with primary school level and $20.7 \%$ for those with secondary school level. 122 women or $57.8 \%$ were exclusively breastfeeding. Contraceptive practice varied according to exclusive breastfeeding with a $\mathrm{p}$ value $=0,030$. Thus $19.3 \%$ of non-lactating clients were on estrogen-progestogen pills compared to $7.4 \%$ for lactating clients. The difference was statistically significant. There was no significant link between contraceptive choice and age, parity, marital status and side effects (Table 3).

Table 3: Factors influencing the choice of contraceptive methods.

\begin{tabular}{|c|c|c|c|c|c|c|}
\hline Contraceptive Methods & Injectables N (\%) & $\begin{array}{c}\text { Oestrogen- } \\
\text { Progestogen Pills } \\
\text { N (\%) }\end{array}$ & $\begin{array}{c}\text { Jadelle Implants } \\
\text { N (\%) }\end{array}$ & $\begin{array}{l}\text { Progestogen } \\
\text { Pills N(\%) }\end{array}$ & IUD N(\%) & Total \\
\hline \multicolumn{7}{|l|}{ Age Group (P Value=0.599) } \\
\hline $15-19$ years & $30(65.2)$ & $5(10.9)$ & $6(13.0)$ & $5(10.9)$ & $0(0.0)$ & 46 \\
\hline $20-24$ years & $118(65.8)$ & $26(14.1)$ & $23(12.4)$ & $12(6.5)$ & $6(3.2)$ & 185 \\
\hline \multicolumn{7}{|l|}{ Parity $(P$ value $=0.149)$} \\
\hline Nulliparous clients & $7(43.8)$ & $3(18.8)$ & $5(31.3)$ & $1(6.3)$ & $0(0.0)$ & 16 \\
\hline Primiparous clients & $77(73.3)$ & $9(8.6)$ & $11(10.5)$ & $8(7.6)$ & $0(0.0)$ & 105 \\
\hline Pauciparous Clients & $40(56.3)$ & $14(19.7)$ & $9(12.7)$ & $5(7.0)$ & $3(4.2)$ & 71 \\
\hline Multiparous clients & $16(64.0)$ & $3(12.0)$ & $3(12.0)$ & $1(4.0)$ & $2(8.0)$ & 25 \\
\hline Large multiparous clients & $8(57.1)$ & $2(14.3)$ & $1(7.1)$ & $2(14.3)$ & $1(7.1)$ & 14 \\
\hline \multicolumn{7}{|l|}{ Side Effects Amenorrhoea } \\
\hline Yes /No & $9(64.3) / 139(64.1)$ & $1(7.1) / 30(13.8)$ & $4(28.6) / 25(11.5)$ & $0(0.0) / 17(7.8)$ & $\begin{array}{c}0(0.0) / \\
6(2.8)\end{array}$ & $14 / 217$ \\
\hline \multicolumn{7}{|l|}{ Abdominal Pains } \\
\hline Yes /No & $10(100.0) / 138(62.4)$ & $0(0.0) / 31(14.0)$ & $0(0.0) / 29(131)$ & $0(0.0) / 17(7.7)$ & $\begin{array}{c}0(0.0) / \\
6(2.7)\end{array}$ & $10 / 221$ \\
\hline \multicolumn{7}{|l|}{ Migraines, Headaches } \\
\hline Yes / No & $9(100.0) / 139(62.6)$ & $0(0.0) / 31(14.0)$ & $0(0,0) / 29(13.1)$ & $0(0.0) / 17(7.7)$ & $\begin{array}{c}0(0.0) / \\
6(2.7)\end{array}$ & $9 / 222$ \\
\hline
\end{tabular}


Journal of Gynecology and Women's Health

\begin{tabular}{|c|c|c|c|c|c|c|}
\hline Metrorrhagia & & & & & & \\
\hline Yes / No & $7(87.5) / 141(63.2)$ & $0(0.0) / 31(13.9)$ & $1(12.5) / 28(12.6)$ & $0(0,0) / 17(7.6)$ & $\begin{array}{c}0(0.0) / \\
6(2.7)\end{array}$ & $8 / 223$ \\
\hline \multicolumn{7}{|l|}{ Weight Gain } \\
\hline YES / No & $6(75.0) / 142(63.7)$ & $1(12.5) / 30(13.5)$ & $0(0.0) / 29(13.0)$ & $\begin{array}{c}1(12.5) / \\
16(7.2)\end{array}$ & $0(0.0) / 6(2.7)$ & $8 / 223$ \\
\hline \multicolumn{7}{|l|}{ Exclusive Breastfeeding } \\
\hline Yes & $80(65.6)$ & $9(7.4)$ & $15(12.3)$ & $14(11.5)$ & $4(3.3)$ & 122 \\
\hline No & $58(65.9)$ & $17(19.3)$ & $8(9.1)$ & $3(3.4)$ & $2(2.3)$ & 88 \\
\hline \multicolumn{7}{|l|}{$P$ value $=0.030$} \\
\hline \multicolumn{7}{|l|}{ School level } \\
\hline Uneducated & $59(64.8)$ & $14(15.4)$ & $8(8.8)$ & $6(6.6)$ & $4(4.4)$ & 91 \\
\hline Primary school level & $54(70.1)$ & $4(5.2)$ & $12(15.6)$ & $6(7.8)$ & $1(1.3)$ & 77 \\
\hline Secondary school level & $34(58.6)$ & $12(20.7)$ & $6(10.3)$ & $5(8.6)$ & $1(1.7)$ & 58 \\
\hline$P$ value $=0.008$ & & & & & & \\
\hline
\end{tabular}

\section{Discussion}

The frequency of enrolment of adolescent girls and young women was $32.2 \%$. this rate was close to that of SARR [3] in Senegal in 2013, whose findings were $30 \%$ of female clients under 25 years of age. The average age of the clients was 21.2 years, with the 19-24 age group predominating, accounting for $80 \%$ of the clients compared to $20 \%$ for the $15-19$ age group. Haidara [4] in Senegal in 2013 out of a young population of female, students found an average age of 23.7 years while LY [5] in 2001, out of a population of female adolescents, found an average age of 18 years.

As for the marital status, the majority of our clients (87.9\%) were married. Most African authors had made the same observation. Indeed, Sanogo in Senegal [6] had found 90\% of married women. This predominance of married women could be explained by the fact that in Senegal the majority of women (66\%) are married [7] and that marriage is the favorable framework for sexual activity and procreation. Thus, married women are more likely to attend Family Planning services without fear of being judged negatively, unlike young adolescent girls, single women and widows. Marital status thus has a significant impact on contraceptive practice in our context. Regarding the educational level, most clients were illiterate (40\%), followed by clients with primary school level (33.3\%) and clients with secondary school level (25.1\%). These results are very similar to those found by LY [5] in Dakar, Senegal in 2001, on a study of contraception among adolescent girls, with $45.3 \%$ illiterate, $37.1 \%$ having primary school level and 30.3\% having secondary school level.

In our study, five modern contraceptive methods were mainly used by our clients. These were, first, injectables (64.1\%), the estrogen-progestogen pill (13.4\%), Jadelle implants (15.6\%), the progestogen pill $(7.4 \%)$ and the intrauterine device $(2.6 \%)$ of the clients. Our results are not far from those of GUINDO in Mali in 2005[8] where $50 \%$ of clients had opted for injectables, $32.7 \%$ for oral contraceptives and 15.1\% for IUD. Sarr [3] in Senegal in 2013 at the Dakar Institute of Social Hygiene also found that five contraceptive methods were mainly used by clients for age groups under 20 and between 20 and 24 . Thus, for the under-20 age group, Sarr [3] found $48.4 \%$ for injectable, $25 \%$ for oral contraceptives, $19.2 \%$ for the implant and $7.4 \%$ for the IUD. For the 20-24 age group, Mrsa [3] found 48.9\% for injectables, $28 \%$ for oral contraceptives, $14.1 \%$ for implant and $8.9 \%$ for IUD. This predominance of injectable and oral contraceptives over longterm methods (IUDs and implants) in our study is supported by the results of the latest demographic and health survey in Senegal [7].

According to the Continuous Demographic Health Survey (DHS-C) 2014 [7], only 4.1\% of women aged 15-19 years used modern contraception, with a preference for the pill for $1.6 \%$ and the injectable method for $1.1 \%$. For women aged 20 to 24 years old, the Senegal 2014 Continuous Demographic and Health Survey (DHS) showed that of the $8.1 \%$ of women who used a modern contraceptive method, $3.6 \%$ used the injectable method followed by those who use implants $1.7 \%$ and then those using pills $1.1 \%$ of women in this age group [7,8]. As for injectable contraceptives, their easy use (one injection every 3 months) could be a factor influencing clients' choices. The low use of the IUD in Senegal $(0.4 \%)$ according to the C-DHS and Nguer [9], is due to rumors about it, in particular the possibility of IUD migration, the occurrence of pelvic inflammatory disease, cervical cancer and also to its insertion, which requires a good command of the technique.

Analysis of the side effects shows that $19.9 \%$ of the clients noted that they were dominated by secondary amenorrhea (30.4\%), followed by pelvic pain $(21.7 \%)$ and migraines or headaches (19.6\%). LY [7] in Dakar, Senegal in 2001 showed that secondary amenorrhea is the most common side effect among injectable clients (27.7\%). According to Sarr [3] 39.9\% of clients with weight gain were on injectable contraceptives (50.9\%) and $25.3 \%$ were on oral contraceptives. In our study, the continuity 
rate varied according to contraceptive choice with a p value of < 0.000 . Active clients predominated at $49.8 \%$. There was also a fairly high rate of loss of contact, representing $42.9 \%$ of clients. Abandons and stops represented $4.8 \%$ and $2.6 \%$ of clients respectively. The active ingredients were mainly under injectables $59.1 \%$ or under jadelle implant $(22.6 \%)$. Of the clients who had dropped out, $63.6 \%$ were on injectables and $36.4 \%$ on progestin-only pills. The active ingredients were mainly under injectable $(59.1 \%)$ or jadelle $(22.6 \%)$. Of the clients who had dropped out, $63.6 \%$ were on injectables and $36.4 \%$ on progestin-only pills. According to DHS-continue Senegal 2014 [7], the overall 12 -month discontinuity rate of contraceptive methods is $34.4 \%$, in which $41.3 \%$ of clients were under injectables and $37.8 \%$ under oral contraceptives. SARR in Senegal [3] in 2013, during client follow-up, had recorded $6.8 \%$ stoppages, $2.4 \%$ dropouts. In addition, more than half of active clients were implants (69.1\%) and IUD (34.5\%) clients. Moreau [10] had noted an active client rate of $51.7 \%$ for injectable contraceptives, $58 \%$ for the jadelle implant, $63.6 \%$ for the IUD and $71.8 \%$ for oral contraceptives, with an average active client rate of $53.7 \%$. This high rate of lost follow-ups (42.9\%) could be explained by poor client awareness for follow-up or by dissatisfaction with clients who do not continue contraception. Indeed, BA [11] in his study carried out at the Gynecology and Obstetrical clinic at the University Hospital Centre Aristide Le Dantec in 1993, which examined the knowledge, practices and prospects of contraception among adolescent girls, found that there was little knowledge $(17 \%)$ of contraceptive methods among adolescent girls. This was mainly due to a lack of information or inaccuracy in the information given in the field of contraception [12]. The epidemiological profile of pregnant adolescent girls, reveals that most of them are illiterate. As a result, the information conveyed in the population does not reach this target group. In addition, rumors as to contraceptive products are harmful in general also constitute a reluctance to take them [10].

In our study, the uneducated clients and those with secondary school level were more likely to choose the estrogen pill than primary school clients. Thus the distribution of the choice of method varied according to the level of education with a $p$ value $=0.008$. In Burkina Faso and Congo [13] in 2005 we found that educated women, i. e. those with at least primary education, were 7 times more likely to use modern contraception than women with no education. Women's education therefore plays an important role in reducing their fertility. Apparently in Senegal, according to the DHS-continues 2014 Program [2] modern contraceptive prevalence increases with education level. From $14.3 \%$ for those with no schooling, this rate rises to $29.6 \%$ for primary school level clients and $33.4 \%$ for middle and secondary school level clients. These results are different from those found in our study, which show rates of $39.4 \%$ for clients with no schooling followed by clients with primary school level $33.3 \%$ and secondary school level clients $25.1 \%$.
In our study 122 women (57.8\%) were exclusively breastfeeding. Contraceptive practice varied according to exclusive breastfeeding with a $\mathrm{p}$ value $=0,030$. Thus $19.3 \%$ of non-lactating clients were on estrogen-progestogen pills compared to $7.4 \%$ for lactating clients. The difference was statistically significant. This correlation could be explained by the fact that after delivery, more specifically during breastfeeding, estrogen-progesterone are not recommended because they could reduce milk production [1].

\section{Conclusion}

Nowadays, sexuality during adolescence is becoming increasingly early, resulting in unwanted pregnancies and clandestine induced abortions. Therefore, managing this early sexuality and preventing its consequences becomes an imperative through the implementation of a favorable family planning policy, which responds to the reproductive health needs of adolescent girls in our regions.

\section{References}

1. Agence Nationale d'Accréditation et d'Evaluation en Santé (ANAES) (2002) Recommandations pour la pratique clinique: Allaitement maternel, mise en œuvre et poursuite dans les 6 premiers mois de vie de l'enfant. Service des recommandations professionnelles de l'ANAES, Paris mai, pp. 16-17.

2. Région Médicale de Dakar (2014) Réunion de coordination régionale trimestre: 4 de l'année 2013; Présentation du district sanitaire de Pikine.

3. Sarr T (2013) Prestations de services de contraceptions àl'institut d'hygiène sociale de Dakar: bilan de 10annees d'activités (de janviers 2000 à décembre 2009). Thèse médecine (Sénégal) 114: 124.

4. Haidara R (2015) Connaissances, attitudes et pratiques de la contraception et de la prévention des infections sexuellement transmissibles en milieu estudiantin: enquête chez les étudiantes de l'université cheikh Anta Diop de Dakar/Sénégal. Mémoire DES gynécologie - obstétrique (Sénégal) 1033: 62-77.

5. Ly P (2001) Contraception chez l'adolescente àDakar: Etude Multicentrique de 246 cas. Thèse, Faculté de Médecine et de Pharmacie, $\mathrm{N}^{\circ}$ 57, Dakar, p. 42986.

6. Sanogo D, Ramarao S, Jones H, Ndiaye P, Mbow B, et al. (2003) Improving quality of care and use of contraceptives in Senegal. Afr J Reprod Health $7(2)$ : 57-73.

7. Agence Nationale de la Statistique et de la Démographie (ansd) et ICF International (2012-2013) Enquête Démographique et de Santé Continue (EDS-Continue) au Sénégal 2012- 2013. ANDS et ICF International, USA, p. 37-42.

8. Guindo AS (2005) Évaluation de la qualité des services dans les six unités de planification familiale des CSREF du district de Bamako. Thèse Méd Bamako (Mali), pp. 73-76.

9. Nguer R, Reynolds HW (2004) Évaluation de la baisse de l'utilisation du DIU au Sénégal. USAID, Direction de la Santé de la Reproduction (DSR), Family Health International (FHI), USA, pp. 8-39.

10. Moreau JC, Sangare M, Diouf A, Gueye BM, Diallo D, et al. (1994) Place du Norplant dans le Choix contraceptif. Afrique Médical 307: 5-11.

11. Ba MG, Sankare M, Moreira P, Bah MD, Diadhiou F, et al. (1999) Connaissance, pratique et perspectives de la contraception chez les adolescents. Med Afr noire 46(6): 300-302. 
12. Ndiaye $\mathrm{P}$, Nare $\mathrm{C}$ (1995) Les contraintes et barrières à l'utilisation des services de planification familiale pour les femmes et les adolescentes The Pop. Council, Dakar.
13. Zakari C (1998) Les facteurs de la contraception au Burkina Faso, analyse des données de l'enquête démographique et de santé de 1998 /99, La planification familiale en Afrique, documents d'analyse 5: 53.

\section{Your next submission with Juniper Publishers will reach you the below assets}

- Quality Editorial service

- Swift Peer Review

- Reprints availability

- E-prints Service

- Manuscript Podcast for convenient understanding

- Global attainment for your research

- Manuscript accessibility in different formats ( Pdf, E-pub, Full Tsext, Audio)

- Unceasing customer service

Track the below URL for one-step submission https://juniperpublishers.com/online-submission.php 
